\title{
Embolisation of superior gluteal artery pseudoaneurysm, after hip cephalomedullary nail revision
}

\author{
Mithun Nambiar, ${ }^{1,2}$ David Ng (1) , Julian Maingard, ${ }^{1,2}$ John Vrazas ${ }^{4,5}$
}

${ }^{1}$ Monash Imaging, Monash Health, Clayton, Victoria, Australia

${ }^{2}$ Faculty of Medicine, Nursing and Health Sciences, Monash University, Clayton, Victoria, Australia

${ }^{3}$ Interventional Radiology, Eastern Health, Box Hill, Victoria, Australia

${ }^{4}$ Interventional Radiology, St Vincent's Private Hospital, East Melbourne, Victoria, Australia ${ }^{5}$ Faculty of Medicine, Dentistry and Health Sciences, University of Melbourne, Parkville, Victoria, Australia

\section{Correspondence to}

Dr David Ng;

davidng132@gmail.com

Accepted 20 December 2021

Check for updates

(C) BMJ Publishing Group Limited 2022. No commercial re-use. See rights and permissions. Published by BMJ.

To cite: Nambiar M, Ng D, Maingard J, et al. BMJ Case Rep 2022;15:e247322. doi:10.1136/bcr-2021247322

\section{DESCRIPTION}

An 84-year-old woman sustained a periprosthetic left hip fracture after a fall, and underwent revision internal fixation with a long cephalomedullary nail, with the operation involving removal of the broken nail as well as reinsertion of a new cephalomedullary nail (InterTan, Smith \& Nephew, Memphis, TN, USA) (figure 1). Approach was via lateral incisions to approach the femoral shaft as well as the piriformis entry point.

The patient's preoperative haemoglobin was $139 \mathrm{~g} / \mathrm{L}$ (normal 120-155 g/L). The operation itself was uncomplicated without notable blood loss. Day 1 postoperative haemoglobin was 108 . The patient was discharged to rehabilitation 5 days after surgery. During the time of rehabilitation, the patient fell against her chair, and subsequently noticed pain with swelling at the surgical site. She was readmitted on day 14 after initial operation, with a haemoglobin of $92 \mathrm{~g} / \mathrm{L}$. The thigh haematoma began to grow in size with increasing pain and on day 15 the haemoglobin dropped to $72 \mathrm{~g} / \mathrm{L}$. The large haematoma in the left gluteal region was not associated with surgical wound site ooze or dehiscence.

CT scan demonstrated a $12 \times 11 \times 7 \mathrm{~cm}$ haematoma in the left gluteal region, with active haemorrhage from a pseudoaneurysm arising from the superior gluteal artery (SGA) (figure 2).

Attempt was made at ultrasound-guided direct compression, however a repeat CT angiogram demonstrated no effect on the contrast blush from the pseudoaneurysm.
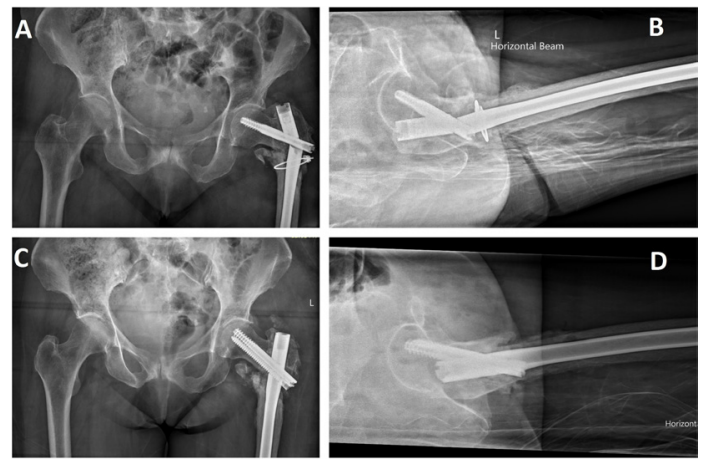

Figure $1(\mathrm{~A}, \mathrm{~B})$ Anteroposterior $(\mathrm{AP})$ and lateral $\mathrm{X}$-rays of a periprosthetic left hip fracture with cephalomedullary nail failure. $(C, D) A P$ and lateral $X$-rays of revision cephalomedullary nail (InterTan, Smith \& Nephew, Memphis, Tn, USA).

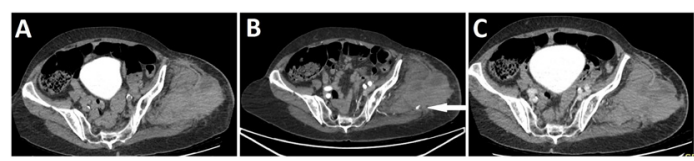

Figure 2 Axial CT scans, (A) precontrast image demonstrating a left gluteal haematoma, note that the patient had a recent contrast study and hence has contrast in the bladder, (B) arterial phase study demonstrating active site of extravasation (white arrow), (C) postcontrast portal venous phase study demonstrating pooling of contrast within the haematoma.

The bleeding pseudoaneurysm was accessed via a retrograde right common iliac artery sheath. Embolisation was performed via $3 / 2 \mathrm{~mm}$ Tornado micro-coils (Cook Medical, Bloomingdale, IN, USA) and 500-700 $\mu \mathrm{m}$ contour polyvinyl embolisation particles (Boston Scientific, Marlborough, MA, USA) (figure 3). The patient was transfused with one unit packed red blood cells. Postprocedure haemoglobin was 84 , with no further enlargement of the haematoma, or haemoglobin drop. The patient was discharged.
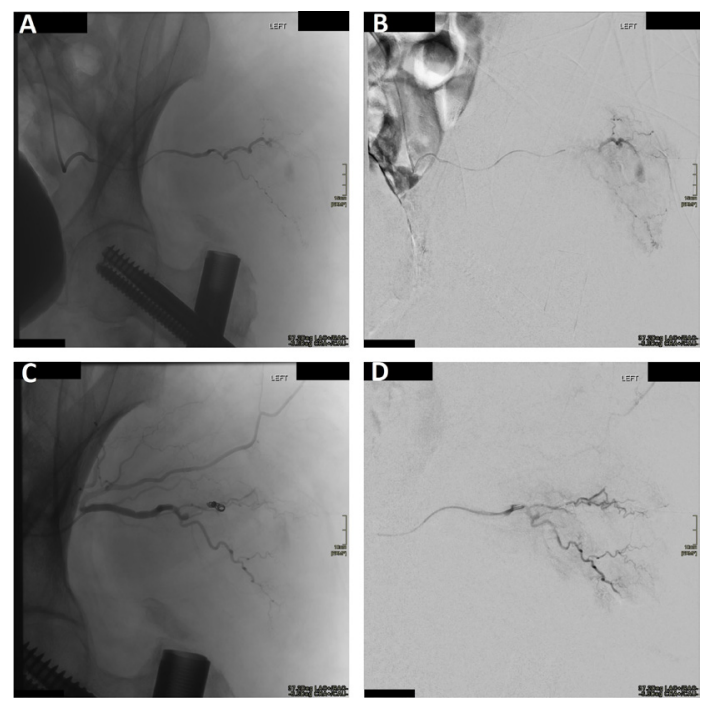

Figure $3 \quad(A, B)$ Super-selective runs of the superior gluteal artery demonstrate the pseudoaneurysm, with extravasation of contrast causing a 'blush', as well as vessel irregularity as a result of vasospasm which is a physiological attempt at arresting the haemorrhage. (C,D) Postembolisation runs demonstrate coil and particle embolisation of the superior gluteal artery, and cessation of haemorrhage. 
Vascular complications are a potentially life-threatening adverse event after hip fracture fixation. While pseudoaneurysms of the profundal femoris artery, due to the zone of injury and proximity to the femoral nail are well described, injury to the gluteal arteries as a result of internal fixation are very rare. To our knowledge there have only been three previously described case reports of injury to the SGA after hip fracture internal fixation with a cephalomedullary nail. ${ }^{1-3}$ Injury to the SGA can occur during guidewire insertion, reaming, as well as nail insertion. Previously described cases were primary procedures for hip fractures, while our case is the first described revision case resulting in SGA. Revision surgery can require more extensive dissection and

\section{Learning points}

- Vascular injury is a rare but potentially serious complication of hip fracture internal fixation.

- Vascular injury should be considered in cases of postoperative haemoglobin level drop.

- Investigation with CT angiogram is a useful modality to investigate sites of bleeding, which can guide angioembolisation. instrumentation that can injure surrounding neurovascular structures.

Contributors MN- data collection, literature review, drafting manuscript, DN- data collection, drafting manuscript, JM- drafting manuscript, JV- performing procedure, drafting manuscript.

Funding The authors have not declared a specific grant for this research from any funding agency in the public, commercial or not-for-profit sectors.

Competing interests None declared.

Patient consent for publication Consent obtained directly from patient(s).

Provenance and peer review Not commissioned; externally peer reviewed.

Case reports provide a valuable learning resource for the scientific community and can indicate areas of interest for future research. They should not be used in isolation to guide treatment choices or public health policy.

\section{ORCID iD}

David Ng http://orcid.org/0000-0002-4069-4460

\section{REFERENCES}

1 Ailaney N, O'Connell R, Giambra L, et al. Superior gluteal artery pseudoaneurysm following intramedullary nailing of an atypical femoral fracture. BMJ Case Rep 2019;12. doi:10.1136/bcr-2019-231490. [Epub ahead of print: 23 Oct 2019].

2 Carroll C, Warren M, Nammour M, et al. Superior gluteal artery bleed after Cephalomedullary nail fixation. Ochsner J 2020;20:339-42.

3 Ward JP, Strauss EJ, Tejwani NC. Injury to the superior gluteal artery during intramedullary fixation of an atypical subtrochanteric stress fracture - a case report. Bull Hosp Jt Dis 2013;71:297-300.

Copyright 2022 BMJ Publishing Group. All rights reserved. For permission to reuse any of this content visit https://www.bmj.com/company/products-services/rights-and-licensing/permissions/

BMJ Case Report Fellows may re-use this article for personal use and teaching without any further permission.

Become a Fellow of BMJ Case Reports today and you can:

- Submit as many cases as you like

- Enjoy fast sympathetic peer review and rapid publication of accepted articles

- Access all the published articles

Re-use any of the published material for personal use and teaching without further permission

Customer Service

If you have any further queries about your subscription, please contact our customer services team on +44 (0) 2071111105 or via email at support@bmj.com.

Visit casereports.bmj.com for more articles like this and to become a Fellow 